\title{
Cystamine Potently Suppresses In Vitro HIV Replication in Acutely and Chronically Infected Human Cells
}

\author{
Alberto Bergamini," Marcella Capozzi,* Lina Ghibelli," Luciana Dini,, Agata Salanitro," Giuseppe Milanese," \\ Thomas Wagner," Simone Beninati, ${ }^{*}$ Caterina Delfina Pesce,' Carla Amici," and Giovanni Rocchi* \\ *Departments of Public Health, ${ }^{\ddagger}$ Biology, and 'Experimental Medicine, University of Rome "Tor Vergata," 00173, Rome, Italy, \\ ${ }^{\S}$ Department of Biology, University of Lecce, 73100, Lecce, Italy, "Department of Molecular Genetics and Cell Biology, The University \\ of Chicago, Chicago, Illinois 60637
}

\begin{abstract}
We have investigated the effects of cystamine on the replication of human immunodeficiency virus (HIV) in human lymphocytes and macrophages, the natural targets of HIV in vivo. Treatment of chronically infected macrophages with cystamine, at a concentration $(500 \mu \mathrm{M})$ that did not show any cytotoxic or cytostatic effects, strongly decreased ( $>80 \%$ ) HIVp24 antigen production and completely abolished the production of infectious viral particles. Cystamine does not affect viral transcription, translation or protein processing; indeed, all HIV proteins are present in a pattern similar to that of nontreated cells. Instead, cystamine interferes with the orderly assembly of HIV virions, as shown by electron microscopy analysis, that reveals only defective viral particles in treated cells. Moreover, suppression of HIV replication, due to the inhibition of proviral DNA formation was observed in acutely infected lymphocytes and macrophages pretreated with cystamine. These results show that cystamine potently suppresses HIV replication in human cells by contemporaneously blocking at least two independent steps of the viral life cycle, without affecting cell viability, suggesting that this compound may represent a new possibility towards the treatment of HIV-1 infection. (J. Clin. Invest. 1994. 93:2251-2257.) Key words: HIV • cystamine • macrophages $\bullet$ lymphocytes
\end{abstract}

\section{Introduction}

A large number of $\mathrm{HIV}$-1-infected patients are now receiving antiretroviral treatment with zidovudine or didanosine (1-3). These compounds work as inhibitors of reverse transcriptase, a viral enzyme acting at an early stage of virus replication $(4,5)$. This means that such drugs can indeed protect cells that are as yet not infected but are totally inactive against virus replication in cells that are already infected (chronically infected cells). The uselessness of these antivirals on chronically infected cells, together with the development of drug resistance, may in part explain their limited efficacy in patients treated for prolonged periods $(6,7)$. For these reasons, antiviral drugs able to attack the virus at late stages of its replication cycle (thus potentially

Address all correspondence to Alberto Bergamini, M.D., Cattedra di Malattie Infettive, Dipartimento di Sanità Pubblica, Università "Tor Vergata," Via O. Raimondo, 00173 Roma, Italia.

Received for publication 13 August 1993 and in revised form 19 November 1993.

J. Clin. Invest.

(C) The American Society for Clinical Investigation, Inc. $0021-9738 / 94 / 05 / 2251 / 07 \quad \$ 2.00$

Volume 93, May 1994, 2251-2257 active on chronically infected cells) are urgently required to improve the chances of success in the therapy of HIV infection.

It has been reported recently that thiol-group containing compounds such as $N$-acetylcysteine (NAC) ${ }^{1}$ and glutathione (GSH) may inhibit a postintegrational stage of the HIV life cycle, and indeed suppress viral replication in chronically infected monocytic cells $(8,9)$. Due to their ability to scavenge reactive oxidative intermediates (ROI), directly or by replenishing cellular GSH, these compounds inhibit the activity of NFk-B, a transcription factor required for viral gene expression $(8-10)$.

To better explore the role of thiolic compounds on HIV replication, we undertook an in vitro study to evaluate the potential anti-HIV activity of cystamine, a diamine formed by two molecules of cysteamine linked by a disulphide bond. Indeed, cystamine may increase the levels of intracellular GSH $(11,12)$ and has been shown to act in a nontoxic manner as a scavenger for ROI in rats and mice (13-15). Here we show that cystamine potently inhibits HIV replication in chronically infected human macrophages without affecting cellular functions. Chronically infected macrophages are considered a crucial reservoir of the virus, and one of the major factors responsible for the spreading of HIV throughout the body $(16,17)$. Thus, inhibition of virus production in these cells represents a major goal in the therapy of HIV related diseases. Interestingly, the inhibition of HIV replication by cystamine in chronically infected cells does not seem to be related to the regulation of gene expression as in the case of NAC and GSH $(8,9)$, but rather to some interference with the orderly assembly of viral particles.

In addition we found that cystamine may also inhibit HIV replication in de novo infected human lymphocytes and macrophages by restricting the formation of proviral DNA.

The in vitro anti-HIV activity of cystamine in de novo and chronically infected human lymphocytes and macrophages (the natural targets of HIV in vivo) suggests that this substance could be active against viral replication also in vivo.

\section{Methods}

Cells. Peripheral blood obtained from healthy HIV-negative donors was enriched for mononuclear cells (PBMC) by centrifugation over Ficoll Hypaque. Mature adherent macrophage populations (called $7 \mathrm{~d}$ adherent macrophages) were obtained by incubating $10^{6} \mathrm{PBMC} /$ well in 48-well plates (Costar Corp., Cambridge, MA) for $7 \mathrm{~d}$, followed by extensive washing to remove nonadherent cells. Using this method, the yield after removal of the nonadherent cells was $10^{5}$ macrophages per well. Further details of this procedure are described elsewhere (18).

1. Abbreviations used in this paper: MID, minimum infectious dose; NAC, $N$-acetylcysteine; ROI, reactive oxidative intermediates. 
Macrophages obtained with this method were $<1 \%$ E-rosette positive and $>95 \%$ nonspecific esterase positive (Technicon Instruments, Tarrytown, NY).

Lymphocytes were obtained by distributing PBMC into AB-human serum coated T-75 flasks (Falcon, Basel, Switzerland) to a final concentration of $4 \times 10^{6}$ cells $/ \mathrm{ml}$ of complete medium (containing RPMI1640 , penicillin $100 \mathrm{U} / \mathrm{ml}$, streptomycin $100 \mu \mathrm{g} / \mathrm{ml}$, L-glutamine 0,3 $\mathrm{mg} / \mathrm{ml}$, and $20 \%$ heat inactivated fetal calf serum). After $2 \mathrm{~h}$ of incubation in $5 \% \mathrm{CO}_{2}$ at $37^{\circ} \mathrm{C}$, nonadherent cells were removed by four gentle washes with phosphate buffered saline (PBS) at $37^{\circ} \mathrm{C}$, collected and stimulated with phitohaemoagglutinine (PHA) $(5 \mu \mathrm{g} / \mathrm{ml})$ in T-75 flasks to a final concentration of $2 \times 10^{6}$ cells $/ \mathrm{ml}$ of complete medium for $3 \mathrm{~d}$ in $5 \% \mathrm{CO}_{2}$ at $37^{\circ} \mathrm{C}$.

H9, a T4 cell line chronically infected with HIV-1, was used in selected experiments.

Virus. A monocytotropic strain of HIV-1, HTLV-III ${ }_{\mathrm{Ba}-\mathrm{L}}$ (gift of Drs. S. Gartner, R. C. Gallo, and M. Popovic, National Cancer Institute), and a lymphocytotropic strain of HIV-1, HTLV--III ${ }_{B}$ were used. These will be referred to as $\mathrm{HIV}-1_{\mathrm{Ba}-\mathrm{L}}$ and $\mathrm{HTLV}$-III $\mathrm{B}_{\mathrm{B}}$, respectively. Supernatants from infected cultures of fresh macrophages were used as the source of HIV-1 $1_{\mathrm{Ba}-\mathrm{L}}$; these were filtered and stored in liquid nitrogen before use. Titration to determine infectivity was performed in a primary macrophage system as previously described (19). Supernatants of infected $\mathrm{H} 9$ cells were used as the source of $\mathrm{HTLV}-\mathrm{III}_{\mathrm{B}}$. The minimum infectious dose (MID) of this strain was assessed in the ATH8 cell line $(4,20)$. Comparable TCDI $_{50}$ of the HTLV-III $B$ stock were obtained when titered on normal $\mathrm{T}$ cells.

Chemicals. Zidovudine was obtained from Wellcome (Pomezia, Italy). Cystamine dihydrochloride was purchased from Sigma Chemical Co. (St. Louis, MO).

Toxicity. Cystamine toxicity in lymphocytes and in $\mathrm{H} 9$ cells was evaluated by trypan blue dye exclusion. The effect of cystamine upon viability of uninfected or HIV-infected macrophage cultures was evaluated by counting the number of nuclei (cells were suspended in lysis buffer $\left(10 \mathrm{mM} \mathrm{KCl}, 2 \mathrm{mM} \mathrm{MgCl}_{2}, 0.5 \%\right.$ Triton X-100 in $10 \mathrm{mM}$ Tris- $\mathrm{HCl}, \mathrm{pH} 7.5)$ and the nuclei scored in a counting chamber at the phase contrast microscope. Cystamine toxicity upon cellular protein synthesis in macrophages was evaluated as percentage of inhibition of incorporation of ${ }^{35}$ S $]$ methionine (see below for further details). The effect of cystamine on macrophage function (phagocytosis) was evaluated as the percentage of inhibition of macrophage cells able to phagocyze India ink particles.

Assay of antiviral activity. The anti-HIV efficacy of cystamine was evaluated in macrophages by its addition just after infection (de novo infected cells) or when the infection was already established (chronically infected cells). The assay to evaluate anti-HIV drug efficacy in de novo infected cells has been previously described (18). Briefly, $10^{5} 7 \mathrm{~d}$ adherent macrophages were suspended in complete medium. The cells were challenged with $100 \mathrm{MID} /$ well of $\mathrm{HIV}-1_{\mathrm{Ba}-\mathrm{L}}$, and incubated at $37^{\circ} \mathrm{C}$ in a $\mathrm{CO}_{2}$ incubator. $2 \mathrm{~h}$ after viral exposure, the macrophages were extensively washed to remove excess virus, exposed to various concentrations of cystamine and then cultured under the same conditions and drug concentrations as before. Cells were washed and fed every $7 \mathrm{~d}$.

To evaluate drug activity in chronically infected cells, $7 \mathrm{~d}$ adherent macrophages were infected as described above and cystamine and AZT were added on day 7 after viral challenge. Cells were then washed and fed every $4 \mathrm{~d}$.

Anti-HIV activity of cystamine in lymphocytes was determined as follows: PHA-stimulated PBMC were washed twice with PBS, counted, distributed into $15-\mathrm{ml}$ polyethylene tubes at a concentration of $6 \times 10^{6}$ PBMC/ml and challenged with 100 MID of HTLV-III ${ }_{B}$. The PBMC were incubated in $5 \% \mathrm{CO}_{2}$ at $37^{\circ} \mathrm{C}$ for $2 \mathrm{~h}$ and washed twice in PBS. Then PBMC were inoculated in each well of a 48-well plate, in the presence or the absence of cystamine, at a concentration of $10^{6} \mathrm{cells} / \mathrm{ml}$ of medium supplemented with $10 \mathrm{U} / \mathrm{ml}$ of recombinant Interleukin 2 (IL-2) (Collaborative Research Incorporated, Bedford, MA). Half the volume of supernatant in each well was replaced every 3-4 d.
For the assessment of cystamine activity in $\mathrm{H} 9 \mathrm{~T}$-cells, $2 \times 10^{5}$ cells were seeded in culture tubes (Falcon 2025) in $1 \mathrm{ml}$ of complete medium, then various concentration of cystamine were added to the cultures. Cells were regularly fed every $5 \mathrm{~d}$ with fresh medium and replenished with cystamine.

Viral detection. HIV-p24 antigen production in supernatants was assessed at regular time points (see Results) by a sandwich ELISA (Abbott, Pomezia, Italy).

$H I V$ infectivity assay. On day 21 , the supernatants of control- and cystamine-treated macrophage cultures were collected, filtered, and stored at $-70^{\circ} \mathrm{C}$. Serially diluted aliquots of each supernatant were then added in quadruplicate to $7 \mathrm{~d}$ adherent macrophages. Infection was carried out as described above (see de novo infection). Culture supernatants of these cells were tested for HIV-p24 antigen production $14 \mathrm{~d}$ after infection. From these data, the 50\% tissue culture infectious dose $\left(\mathrm{TCID}_{50}\right)$ was calculated as previously described (21).

Enzymatic amplification. 7-d adherent macrophages were isolated and purified as described above. Macrophage cultures were challenged with the virus and then incubated without or with $500 \mu \mathrm{M}$ cystamine as described above (see de novo infection). $24 \mathrm{~h}$ after infection, wells were extensively washed, macrophages were detached from the wells, and the DNA was extracted as previously described (22).

After ethidium bromide fluorescent quantitation of the amount of DNA, equivalent amounts of each sample were subjected to 30 cycles of polymerase chain reaction (PCR) amplifications in a total volume of $100 \mu l$ using the HIV gag primer pair SK 38/39. The HIV+ control was plasmid DNA (Perkin-Elmer Corp., Norwalk, CT) containing the entire rearranged genome of the HIV-Z6 isolate. Amplified product, a 115-bp sequence in the gag region of the HIV genome was specifically detected by the olygomer-hybridization procedure (23). The SK 19 oligonucleotide probe was end labeled with $\left[{ }^{32} \mathrm{P}\right]$ adenosine triphosphate as previously described (24). X-ray films of polyacrylamide gels were quantified by analysis with an LKB Ultrascan laser densitometer.

Protein synthesis, immunoprecipitation, and immunoblot analysis. To measure protein synthesis, chronically infected cells either treated or untreated with $500 \mu \mathrm{M}$ cystamine, were metabolically labeled with $\left[{ }^{35}\right.$ S]methionine $(500 \mu \mathrm{Ci})$ (Amersham International, BuckinghamShire, England) in methionine free medium for $5 \mathrm{~h}$. After cell lysis, the radioactivity incorporated into acid-insoluble material was determined (25).

HIV proteins were detected by immunoprecipitation using human serum containing anti-HIV antibodies. Cell lysates containing the same amounts of radioactive material were precipitated with the antibody absorbed to protein A-agarose beads (Pharmacia, Piscataway, NJ). After extensive washing, the precipitates were subjected to SDSPAGE $10 \%$ and the gel was autoradiographed. Autoradiograms were quantitated densitometrically using a laser-beam densitometer (Bio Rad Laboratories, Richmond, CA).

For immunoblot analysis, equal amounts of protein $(100 \mu \mathrm{g})$ were separated on $10 \%$ SDS-PAGE gels and electroblotted to nitrocellulose filters as described (25). For immunostaining of viral proteins, the filters were incubated with human sera containing anti-HIV antibodies.

Electron microscopy analysis. For thin section EM analysis, cystamine-treated and mock-treated HIV-infected cultures were processed as described above. On day 21 after viral challenge, macrophage cells were fixed with $2.5 \%$ glutaraldehyde directly in the 48 -well plate. Cells were then detached by gentle scraping, collected by low speed centrifugation and postfixed with $1 \% \mathrm{OsO}_{4}$. After dehydration, the specimens were embedded into Epon resin. Thin sections were stained with uranyl acetate and lead nitrate and observed under a Philips electron microscope.

\section{Results}

Anti-HIV activity of cystamine in de novo infected cells. In a first set of experiments we evaluated the anti-HIV activity of cystamine in de novo infected macrophages and lymphocytes. 
Detectable infection of macrophages and lymphocytes (assessed by HIV-p24 antigen production) was obtained in each experiment performed. HIV was highly cytopathic for cultured lymphocytes therefore these cultures had to be stopped at day 14 after infection. The anti-HIV activity of cystamine was quite similar in lymphocytes and macrophages (Fig. 1). The inhibitory effect by cystamine on p24 antigen production was dose dependent, started at the concentration of $10 \mu \mathrm{M}$, and was maximal at $200 \mu \mathrm{M}$ (Fig. 1). In all of the experiments performed the inhibition of HIV production lasted as long as cystamine was kept in the medium.

Anti-HIV activity of cystamine in chronically infected cells. Macrophages are considered the reservoir of HIV in the body. Indeed, they can be chronically infected with HIV and may produce great amounts of infectious virus for a long time without undergoing cytolysis $(16,26,27)$. To assess the ability of cystamine in suppressing HIV production also in chronically infected cells we added it to macrophages once the infection was established. In these experiments we compared the extent of viral inhibition by cystamine with that obtained by AZT, a drug that does not interfere with HIV production in infected cells $(4,5)$. Cystamine, as opposed to AZT, suppressed HIV replication (as determined by production of HIV-p24 antigen) from chronically infected macrophage cultures (Fig. 2). The inhibitory effect started to manifest itself at $200 \mu \mathrm{M}$ and was maximal at $500 \mu \mathrm{M}$. However, no antiviral activity was seen with concentrations of cystamine below $200 \mu \mathrm{M}$ and total inhibition of p24 antigen production was never obtained even with a concentration $(200 \mu \mathrm{M})$ that was completely active on de novo infected cells.

The antiviral activity of cystamine was even stronger in chronically infected T-cells (H9) with respect to macrophage cells (Fig. 3). Indeed, we obtained inhibition of HIV-p24 production $>99 \%$ with concentration as low as 200 and $100 \mu \mathrm{M}$ cystamine (respectively after 5 and $10 \mathrm{~d}$ of exposure), and $50 \%$ with $50 \mu \mathrm{M}$ Cystamine. Interestingly, to inhibit virus production on $\mathrm{H} 9$ cells are sufficient cystamine concentrations (50 and $100 \mu \mathrm{M}$ ) which are inactive on macrophage cells. These findings could be due to differences in the uptake of cystamine between H9-neoplastic and normal human cells.

It has been reported that interferons may block HIV replication in chronically infected macrophages (28). Macrophages

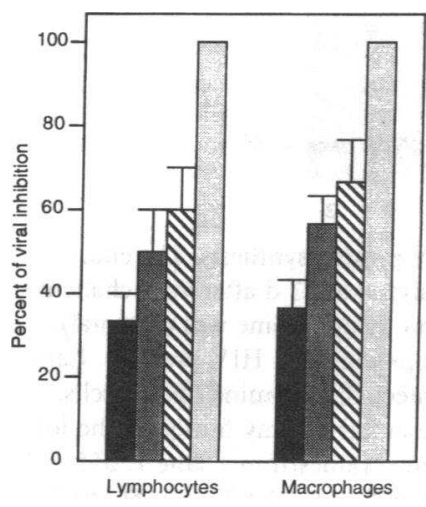

Figure 1. Suppression of p24antigen production by cystamine in de novo infected lymphocytes and macrophages. (ש) Cystamine $10 \mu \mathrm{M}$; ( ${ }^{\circ}$ cystamine $50 \mu \mathrm{M}$; ( $\mathbf{(})$ cystamine $100 \mu \mathrm{M}$; (घ) cystamine 200 $\mu \mathrm{M}$. Results are expressed as percent of virus inhibition compared with positive controls. Assessment of virus replication was performed at $21 \mathrm{~d}$ after infection in macrophages and at $14 \mathrm{~d}$ after infection in lymphocytes. HIV-p24 antigen production in control macrophages (day 21) and lymphocytes (day 14) was $143( \pm 32)$ and $47( \pm 16) \mathrm{ng} / \mathrm{ml}$, respectively. The data represent the averages of four experiments carried out in triplicate. The variability between triplicate results was $<15 \%$.

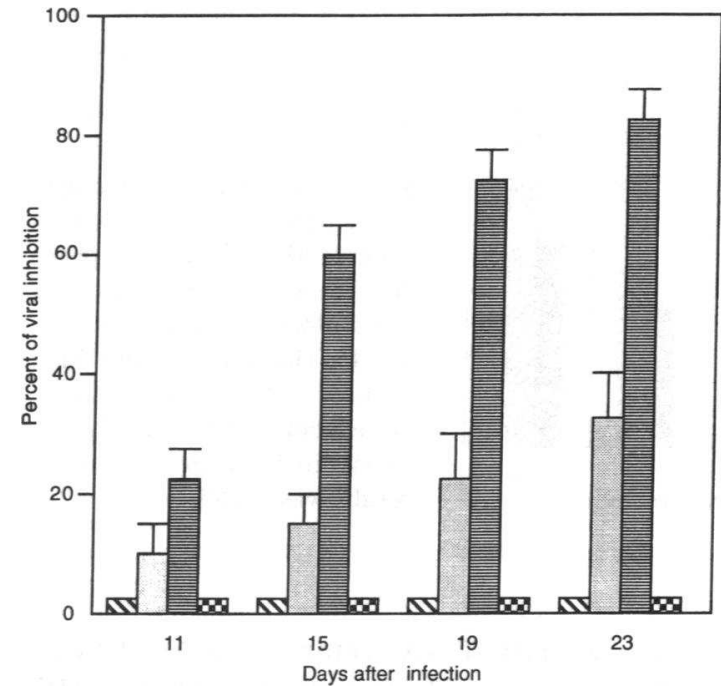

Figure 2. Shut off of viral production in chronically infected macrophages by cystamine. ( $($ ) Cystamine $100 \mu \mathrm{M}$; ( $($ ) cystamine $200 \mu \mathrm{M}$;

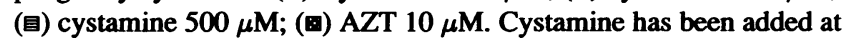
$7 \mathrm{~d}$ after infection. Results are expressed as percent of p24 antigen production compared with positive controls. HIV-p24 antigen production in control macrophages was $131( \pm 42) \mathrm{ng} / \mathrm{ml}$ at day 11,157 $( \pm 38) \mathrm{ng} / \mathrm{ml}$ at day $15,163( \pm 47) \mathrm{ng} / \mathrm{ml}$ at day 19 and $119( \pm 28)$ $\mathrm{ng} / \mathrm{ml}$ at day 23 . The data represent the average of six experiments carried out in triplicate. The variability between triplicate results was $<15 \%$.

produce interferons and are a major source of these cytokine during any infection (29). Due to these observations, we wondered whether cystamine was acting as an interferon inducer. However, no interferon activity (inhibition of encephalomyocarditis virus-induced cytopathic effect in human foreskin fibroblast) (30) was detected in culture fluid of uninfected or HIV-infected macrophages treated or not with cystamine (not shown).

Toxicity. Toxicity data are reported in Fig. 4. Cystamine is not toxic for cultured cells at the concentration which are active against HIV replication. The $\sim 50 \%$ toxic doses were 0.5 $\mathrm{mM}$ for $\mathrm{H} 9$ cells, $2 \mathrm{mM}$ for lymphocytes and uninfected macrophages and $4 \mathrm{mM}$ for chronically infected macrophages. After $14 \mathrm{~d}$ of continuous exposure to cystamine $0.5 \mathrm{mM}$ the rate of total protein synthesis (measured as $\left[{ }^{35} \mathrm{~S}\right]$ methionine incorporation) in uninfected or HIV infected macrophages were similar to that of not cystamine-treated controls $\left(1.97 \times 10^{6}\right.$ and 2.1 $\times 10^{6} \mathrm{CPM} / 1 \mu \mathrm{G}$ of protein versus $1.95 \times 10^{6}$ and $1.9 \times 10^{6}$ $\mathrm{CPM} / 1 \mu \mathrm{G}$ of protein, respectively). Also after $7 \mathrm{~d}$ of exposure to cystamine $0.5 \mathrm{mM}$ the percentage of macrophage cells able to phagocyte India ink particles was similar in control and in treated cells (not shown).

Effect of cystamine upon proviral DNA synthesis. PCR analysis was carried out to determine the effect of cystamine upon proviral DNA formation. DNA was extracted from infected cultures $24 \mathrm{~h}$ after viral challenge, a period that allows only one cycle of HIV replication (31). Using these experimental conditions, the amount of HIV-DNA amplified by PCR should depend on the uncoating and reverse transcriptase steps, since possible interferences of cystamine with virus binding were excluded by adding the compound after viral challenge (see Methods). As shown in Fig. 5, at a concentration of $500 \mu \mathrm{M}$, 


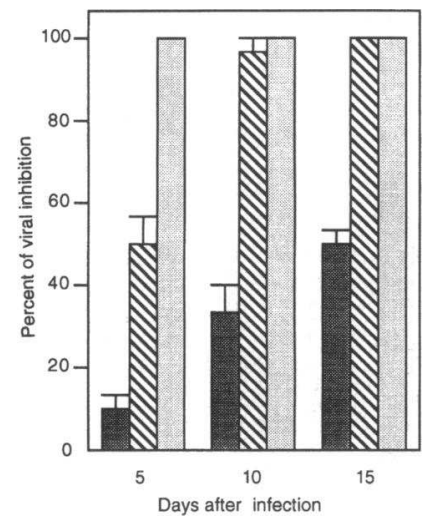

Figure 3. Shut off of viral production in chronically infected

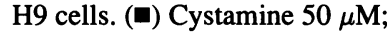
(\$) cystamine $100 \mu \mathrm{M}$; (口) cystamine $200 \mu \mathrm{M}$. Results are expressed as percent of p24 antigen production compared to positive duction in control $\mathrm{H} 9$ cultures was $>300 \mathrm{ng} / \mathrm{ml}$ at days 5,10 , and 15 . The data represent the average of three experiments carried out in duplicate. The variability between duplicate results was $<15 \%$. controls. HIV-p24 antigen pro-

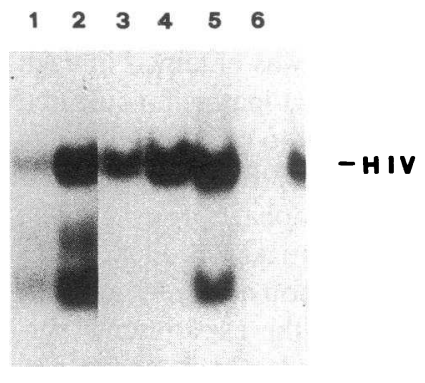

Figure 5. Oligomer-hybridization analysis of HIV gag-amplified (115 bp) products. Lane 1 , amplification of $900 \mathrm{ng}$ of DNA from infected macrophages treated with $500 \mu \mathrm{M}$ cystamine. Lane 2, amplification of $900 \mathrm{ng}$ of DNA from nontreated, HIV-infected macrophages. Lanes 3-5, respectively, $10^{2}, 10^{3}, 10^{4}$, copies of the HIV control plasmid di-

luted in $900 \mu \mathrm{g}$ of human placental DNA. Lane 6, amplification of $900 \mathrm{ng}$ of DNA from mock-infected macrophages. Densitometric analysis of this representative $\mathrm{x}$-ray film gave the following results (measured as absorbance values $/ \mathrm{mm}^{2}$ ): lane $1,21.141$; lane 2, 89.801; lane 3, 14.104; lane 4, 44.343; lane 5, 119.943; lane 6, 0.403 .

treated control (Fig. $6 B$ ). This could be due to impaired release of virus particles from cystamine-treated cells.

Electron microscopy analysis. HIV infection of macrophages cultures resulted in the formation of syncytia producing large amounts of viral particles with the typical morphology of HIV. Indeed, viral particles show the triangular shaped inner core and a well formed capside (Fig. 7, $a$ and $b$ ). The addition of cystamine to infected macrophages cultures caused a dramatic change in viral assembly and budding. Indeed, no mature viruses were found inside or outside the cells; instead viral particles lacking the inner core have been detected inside the cells indicating that proper viral assembly could not take place (Fig. $7, c-e)$.

Noninfectious HIV. The titer of infectious HIV in supernatants of cystamine-treated or untreated macrophage cultures was determined at different time points by endpoint dilution. Fig. 8 shows that in control cells, HIV titer from supernatants collected from day 11 to 23 did not change significantly, while it progressively declined to zero in supernatants from cysta-

A
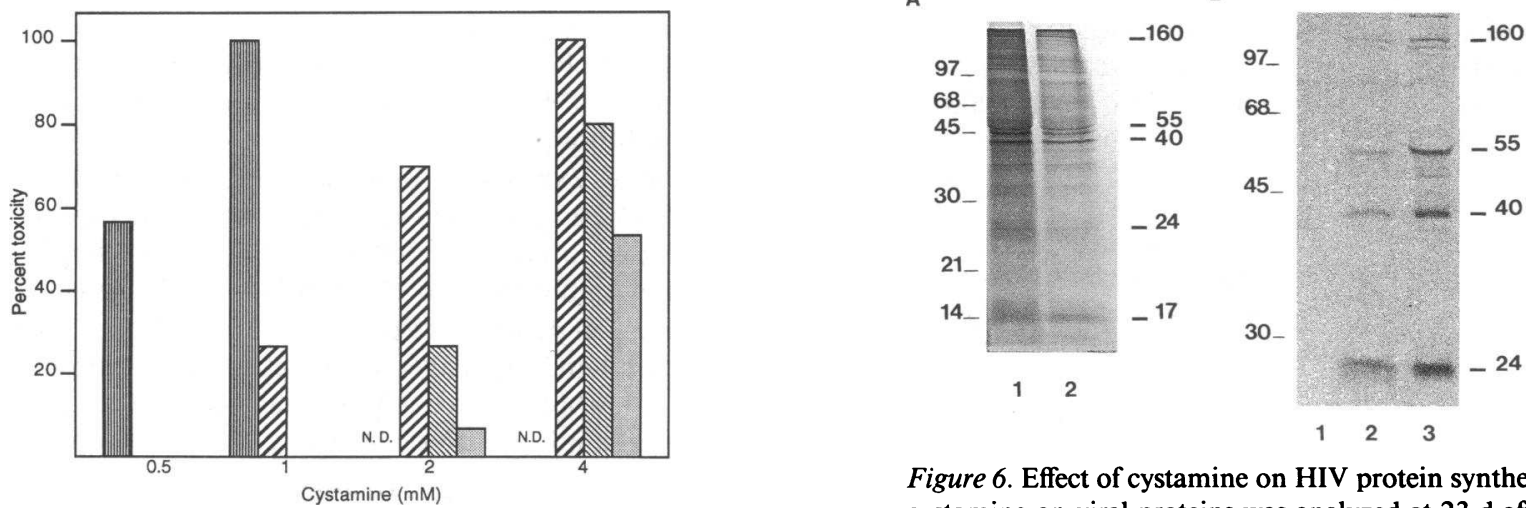

Figure 6. Effect of cystamine on HIV protein synthesis. The effect of cystamine on viral proteins was analyzed at $23 \mathrm{~d}$ after viral challenge (when suppression of $\mathrm{p} 24$ production by cystamine was maximal).

(A) SDS-PAGE analysis of immunoprecipitated HIV proteins. Lane 1 , infected, untreated cells; lane 2 , infected, cystamine treated cells. Densitometric analysis of this representative $x$-ray film gave the following results (measured as absorbance values $/ \mathrm{mm}^{2}$ ): lane $1, \mathrm{p} 55=3$, $09, \mathrm{p} 24=1,63, \mathrm{p} 17=4,00$; lane $2, \mathrm{p} 55=3,10, \mathrm{p} 24=1,86, \mathrm{p} 17$ $=4,07$. (B) Immunoblot analysis of cell lysates. Lane 1 , uninfected control cells; lane 2 , infected, untreated cells; lane 3 , infected, cystamine treated cells. Experiments were repeated three times with identical results. 

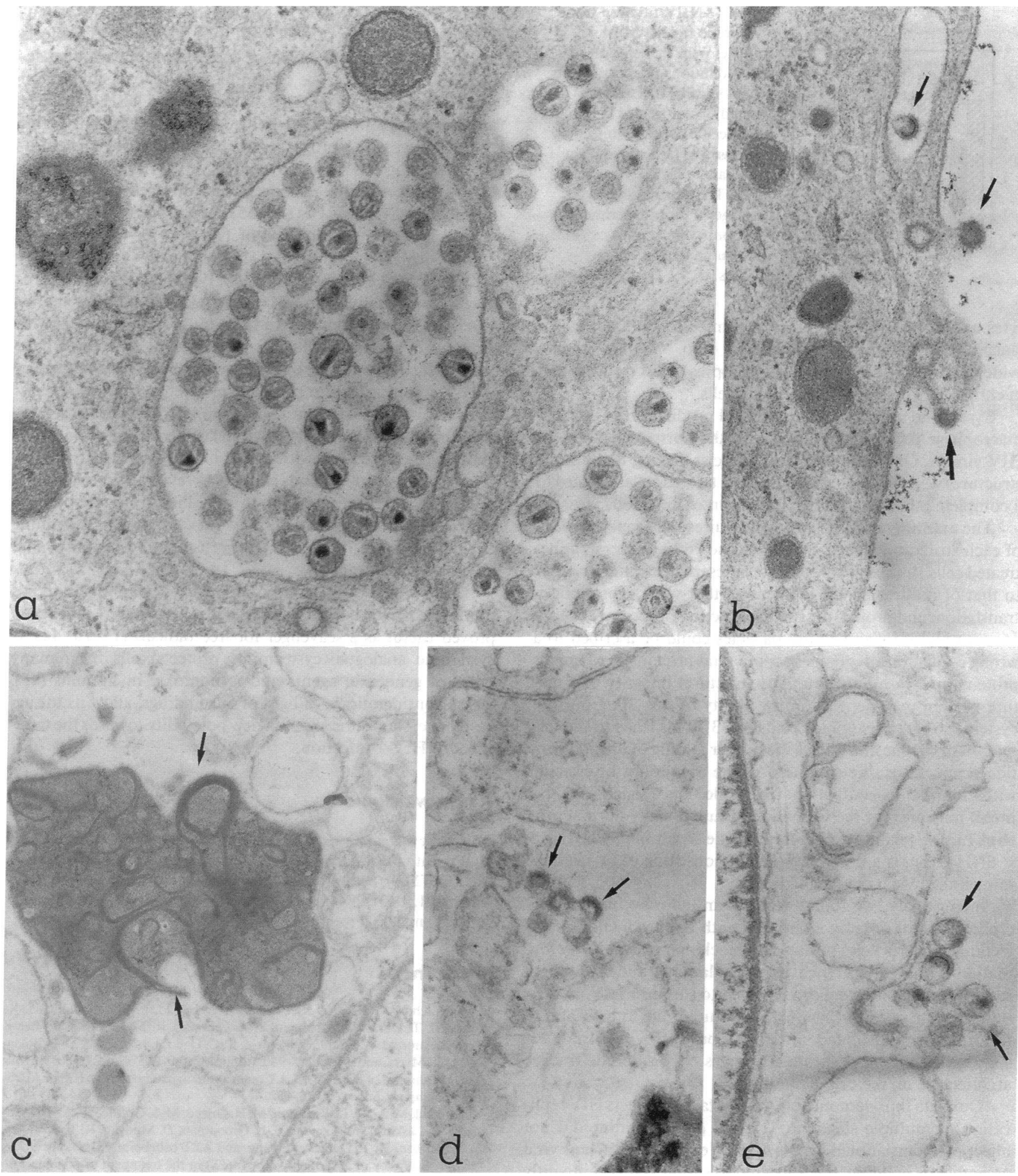

Figure 7. Electron micrographs of infected M/M cultures treated or not with cystamine. ( $a$ and $b$ ) Infected M/M $23 \mathrm{~d}$ after viral challenge. (a) A cytoplasmic vescicle filled with mature virus. (b) Efficient intra- and extracellular viral budding (arrows). (c, $d$, and $e$ ) infected $\mathbf{M} / \mathbf{M}$ after $15 \mathrm{~d}$ of exposure to cystamine $500 \mu \mathrm{M} 23$ (days after viral challenge). (c) Only defective viral particles are found inside the cytoplasmic vescicle. ( $d$ and $e)$ Intra- and extracellular budding of defective virions (arrows). ( $a$ and $c) \times 56,000 ;(b$ and $d) \times 45,000 ;(c) \times 30,000$.

mine-treated cultures. The lack of infectious viruses in spite of the residual HIV-p24 antigen found in the supernatants of infected cultures exposed to cystamine (Fig. 2) could be due to the presence of virions that did not properly assemble.

\section{Discussion}

In this paper we show that cystamine potently inhibits HIV replication and infectivity in acutely infected human lympho- 


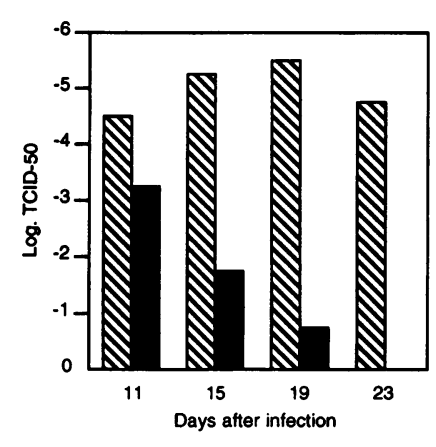

cytes and in acutely and chronically infected human macrophages, the natural targets of HIV in vivo. We also provide evidences that cystamine potently suppresses HIV expression in chronically infected, neoplastic T-cells.

Cystamine suppresses chronic viral production in infecteci macrophage cells by interfering with the normal assembly of HIV virions. Only defective viral particles lacking the internal structures were detectable in cystamine treated cells. This led to a complete inhibition of the production of infectious virus.

The assembly of viral particles requires the proper amount of each structural protein. We have shown that in cystaminetreated cells all capsidic proteins are present in a pattern similar to that of nontreated cells indicating that viral transcription, translation, and protein processing function properly. The lack of assembly of infective viral particles could be ascribed to a wrong configuration of one or more viral proteins as to impair protein-protein interaction. The structural integrity of a mature protein may depend on the ability of free $\mathrm{SH}$ groups of cysteine to form disulphide bridges (33). This leads to the formation of cystine and allows the proper folding of the polypeptide chain. Thus, the oxidation of the $\mathrm{SH}$ groups of cysteine with compounds containing disulphide bonds (such as cystamine) may prevent the formation of functionally normal proteins (33). Cystamine, (2,2'-dithio-bis[ethylamine], $\mathrm{CH}_{2} \mathrm{H}_{7} \mathrm{NS}$ $=\mathrm{SNH}_{7} \mathrm{CH}_{2}$ ), is a dimeric molecule consisting of two cysteamine linked via a disulphide bond.

Interestingly, we found that cystamine may inhibit HIV replication not only by interfering with the production of infectious viral particles but also by blocking proviral DNA formation. Other thiols, such as penicillamine, and 2,3-dimercapto-1-propanol, have been reported to suppress HIV replication in acute systems (34-36). Such thiols, due to their ability to form mixed disulphide links with proteins, could limit adsorption of the virus through changes on disulphide bridges architecture on the cell membrane.

Our data thus demonstrate that cystamine affects HIV replication at multiple stages. At $25-100 \mu \mathrm{M}$ cystamine did not affect posttranslational events of HIV expression such as viral assembly or budding, but appeared to suppress predominantly early steps of the viral life cycle. At higher concentrations (200$500 \mu \mathrm{M}$ ), however, cystamine suppressed both early and late steps of HIV replication. Other than a strong and sustained inhibition of HIV replication induced by cystamine, there is an additional reason that makes this therapeutic approach particularly attractive. Recently it has been suggested that tumor necrosis factor-alpha (TNF $\alpha$ ) plays a central role in the progression of AIDS (37). This is consistent with evidence showing that TNF $\alpha$ levels are abnormally high in serum from AIDS patients $(38,39)$. TNF $\alpha$ exerts some of its toxic effects by stimulating the production of ROI (40). Intracellular GSH protects cells by scavenging ROI; however, the oxidant-buffering capacity of cellular GSH can be overcome by excessive stimulation with TNF $\alpha$ (41). Indeed, intracellular levels of GSH have been found decreased in AIDS patients $(42,43)$; increasing TNF $\alpha$ levels together with a progressive reduction of GSH concentration clearly correlate with the progression of AIDS. Thus, drugs such as cystamine, that either replenish intracellular GSH (12) or directly scavenge ROIs (13-15) may protect HIV-infected patients against the toxic effect of TNF $\alpha$.

In conclusion, inhibition of HIV replication and infectivity in de novo and chronically infected lymphocytes and macrophages by cystamine can be considered an important step toward a combined therapy. Indeed, multidrug regimens with compounds acting at different stages of viral replication have been advised to improve the chances of success in the therapy of HIV infection and to prevent the emergence of drug-resistant HIV isolates. Cystamine, that inhibits HIV replication interfering with posttranscriptional stages of viral life cycle can be usefully associated with drugs that inhibit RT activity and in general with all compounds active on pretranscriptional stages of HIV cycle. Moreover, due to the ability to contemporary inhibit two independent steps of HIV life cycle, cystamine could limit the emergence of drug-resistant viral strains even if used as monotherapy.

Cystamine may be administered per os in animals and has been shown to be nontoxic in rats and in mice where it has been proved useful as a scavenger for free radicals (13-15, 44). A cystamine analogue, cysteamine, protects cells from many types of genotoxic agents and is nontoxic in humans (45). These considerations, in light of our findings, allow us to suggest that cystamine could be a new possibility towards the treatment of HIV-1 infection.

\section{Acknowledgments}

This work was supported by grants from the National Research Council, Progetto Finalizzato "Prevenzione e controllo dei fattori di malattia" (FATMA); Sottoprogetto "Studio dei farmaci per l'AIDS," contract $n$. 91.00101.PF41, and by grants from the Italian Istituto Superiore di Sanità, IV Progetto Di Ricerche sull'AIDS.

\section{References}

1. Yarchoan, R., R. W. Klecker, K. J. Weinhold, P. D. Markham, H. K. Lyerly, D. T. Durack, E. Gelmann, S. N. Lehrman, R. M. Blum, D. W. Barry, G. M. Shearer, M. A. Fischl, H. Mitsuya, R. C. Gallo, J. M. Collins, D. P. Bolognesi, C. E. Myers, and S. Broder. 1986. Administration of 3'-azido-3'-deoxythymidine, an inhibitor of HTLV-III/LAV replication, to patients with AIDS or AIDSrelated complex. Lancet. 1:575-580.

2. Fischl, M. A., D. D. Richman, M. H. Grieco, M. S. Gottlieb, P. A. Volberding, O. L. Laskin, S. M. Leedom, J. E. Groopman, D. Mildvan, R. T. Schooley, G. G. Jackson, D. T. Durack, D. King, and AZT collaborative working group. 1987. The efficacy of azydothymydine (AZT) in the treatment of patients with AIDS and AIDS related complex. N. Engl. J. Med. 317:185-191.

3. Yarchoan, R., H. Mitsuya, R. W. Thoma, J. M. Pluda, N. R. Hartman, C. F. Perno, K. S. Marczyk, J. P. Allain, D. G. Johns, and S. Broder. 1989. In vivo activity against $\mathrm{HIV}$ and favorable toxicity profile of $2^{\prime}, 3^{\prime}$-dideoxyinosine. Science (Wash. DC). 245:412-417.

4. Mitsuya, H., K. J. Weinhold, P. A. Furman, M. H. St. Clair, R. C. Nusinoff Lehrman, R. C. Gallo, D. Bolognesi, D. W. Barry, and S. Broder. 1985. 3'-azido3'-deoxythymidine (BW A509U): an antiviral agent that inhibits the infectivity and cytopathic effect of human T-lymphotropic virus type-III-lymphadenopathy-associated virus in vitro. Proc. Natl. Acad. Sci. USA. 82:7096-7101.

5. Furman, P. A., J. A. Fyfe, M. St. Clair, K. Weinhold, J. L. Rideout, G. A. Freeman, S. N. Lehrman, D. P. Bolognesi, S. Broder, H. Mitsuya, and D. W. 
Barry. 1986. Phosphorylation of 3 '-azido-3'-deoxythymidine and selective interaction of the 5'-triphosphate with human immunodeficiency virus reverse transcriptase. Proc. Natl. Acad. Sci. USA. 83:8333-8337.

6. St. Clair, M. H., J. L. Martin, G. Tudor-Williams, M. C. Bach, C. L. Vavro, D. M. King, P. Kellam, S. D. Kemp, and B. A. Larder. 1991. Resistance to ddl and sensitivity to AZT induced by a mutation in HIV-1 reverse transcriptase. Science (Wash. DC). 1253:1557-1559.

7. Fitzgibbon, J. E., R. M. Howell, C. A. Haberzettl, S. J. Sperper, D. J. Gocke, and D. T. Dubin. 1992. Human immunodeficiency virus type 1 pol gene mutation which cause decreased susceptibility to $2^{\prime}, 3^{\prime}$-deoxycytidine. Antimicrob. Agents Chemother. 36:153-157.

8. Roederer, M., F. J. T. Staal, P. A. Raju, S. W. Ela, L. A. Herzenberg, and L. A. Herzenberg. 1990. Cytokine-stimulated human immunodeficiency virus replication is inhibited by N-acetyl-L-cysteine. Proc. Natl. Acad. Sci. USA. 87:4884-4888.

9. Kalebic, T., A. Kinter, G. Poli, M. E. Anderson, A. Meister, and A. S. Fauci. 1991. Suppression of human immunodeficiency virus expression in infected monocytic cells by glutathione, glutathione ester and $\mathrm{N}$-acetylcysteine. Proc. Natl. Acad. Sci. USA. 88:986-990.

10. Staal, F. J. T., M. Roederer, L. A. Herzenberg, and L. A. Herzenberg. 1990. Intracellular thiols regulate activation of nuclear factor Kappa B and transcription of human immunodeficiency virus. Proc. Natl. Acad. Sci. USA. 87:9943-9947.

11. Meister, A., M. E. Anderson, and O. Hwang. 1986. Intracellular cysteine and glutathione delivery systems. J. Am. Coll. Nutr. 5:137-151.

12. Djurhuus, R., A. M. Svardal, M. A. Mansoor, and P. M. Ueland. 1991. Modulation of glutathione content and the effect on methionine auxotrophy and cellular distribution of homocysteine and cysteine in mouse cell lines. Carcinogenesis (Oxf.). 12:241-247.

13. Nagiel-Ostaszewski, I., and C. A. Lau-Cam. 1990. Protection by pantethine, pantothenic acid and cystamine against carbon tetrachloride-induced hepatotoxicity in the rat. Res. Commun. Chem. Pathol. Pharmacol. 67:289-292.

14. Vasin, M. V., I. N. Chernov, and L. A. Semenova. 1991. Antiradiation properties of radioprotectors, immunomodulators and agents affecting tissue metabolism in fractionated irradiation. Radiobiologiya. 31:271-275.

15. Kozubic, A., M. Pospisil, and J. Netikova. 1991. Possibilities of the combined use of non-steroidal anti-inflammatory drugs and sulphidril compounds in radioprotection. Strahlenther. Onkol. 167:186-190.

16. Gartner, S., P. Markovits, D. M. Markovits, M. H. Kaplan, R. C. Gallo and M. Popovic. 1986. The role of mononuclear phagocytes in HTLV-III/LAV infection. Science (Wash. DC). 233:215-219.

17. Meltzer, M. S., D. R. Skillman, P. J. Gomatos, D. C. Kalter, and H. E. Gendelman. 1990. Role of mononuclear phagocytes in the pathogenesis of human immunodeficiency virus. Annu. Rev. Immunol. 8:169-194.

18. Perno, C. F., R. Yarchoan, D. A. Cooney, N. R. Hartman, S. Gartner, M. Popovic, Z. Hao, T. L. Gerrard, J. A. Wilson, D. G. Johns, and S. Broder. 1988. Inhibition of human immunodeficiency virus (HIV-1/HTLV-III Ba-L $_{\text {L }}$ replication in fresh and cultured human peripheral blood monocytes/macrophages by azidothymidine and related 2', 3'-dideoxy-nucleosides. J. Exp. Med. 168:1111-1118.

19. Perno, C. F., M. W. Baseler, S. Broder, and R. Yarchoan. 1990. Infection of monocytes by human immunodeficiency virus type 1 blocked by inhibitors of CD4-gp 120 binding, even in the presence of enhancing antibodies. J. Exp. Med. 171:1043-1056

20. Mitsuya H., and S. Broder. 1986. Inhibition of the in vitro infectivity and cytopathic effect of human T-lymphotropic virus type-III-lymphadenopathy-associated virus (HTLV-III/LAV) by 2',3'-dideoxynucleosides. Proc. Natl. Acad. Sci. USA. 83:1911-1920.

21. Karber, G. 1931. Beitrag zur kollektiven behandlung pharmakologisker reihenversuche. Arch. Exp. Pathol. Pharmakol. 162:480-483.

22. Maniatis, T., E. F. Fritsch, and J. Sambrook. 1982. In Molecular cloning: a laboratory manual. 1st Edition. Cold Spring Harbor Laboratory Press, Cold Spring Harbor, NY 280-281.

23. Kellogg, D. E., and S. Kwok. 1990. Detection of human immunodeficiency virus. In PCR Protocols. A guide to Methods and Applications. M. A. Innis, D. H. Gelfand, J. J. Sninsky, and T. J. White, editors. Academic Press, Inc. San Diego, CA. 337-347.

24. Sambrook, J., E. F. Fritsch, and T. Maniatis. 1989. Molecular cloning: A Laboratory Manual. 2nd edition. Cold Spring Harbor Laboratory Press, Cold Spring Harbor, NY 1131-1133.

25. Amici, C., and M. G. Santoro. 1991. Suppression of virus replication by prostaglandin A is associated with heat shock protein synthesis. J. Gen. Virol. 72:1877-1855.

26. Ho, D. D., T. R. Rota, and M. S. Hirsch. 1986. Infection of monocytes/ macrophages by. J. Clin. Invest. 77:1712-1718.

27. Salahuddin, S. Z., R. M. Rose, J. E. Groopman, P. D. Markham, and R. C. Gallo. 1986. Human T-lymphotropic virus type III infection of human alveolar macrophages. Blood. 68:281-295.

28. Gendelman, H. E., L. M. Baca, J. Turpin, D. C. Kalter, B. Hansen, J. M Orenstein, C. W. Dieffenbach, R. M. Friedman, and M. S. Meltzer. 1990. Regulation of HIV replication in infected monocytes by IFN-alpha. Regulation of HIV replication in infected monocytes by IFN-alpha. Mechanisms for viral restriction. J. Immunol. 145(8):2669-2676.

29. Gendelman, H. E., R. M. Friedman, S. Joe, L. M. Baca, J. A. Turpin, G. Dveksler, M. S. Meltzer, and C. Dieffenbach. 1990. A selective defect of interferon $\alpha$ production in human immunodeficiency virus-infected monocytes. $J$. Exp. Med. 172:1433-1442.

30. Yeh, T. J., P. T. McBride, J. C. Overall, and J. A. Green. 1982. Automated, quantitative cytopathic effect reduction assay for interferon. Clin. Microbiol. 16:413-420.

31. Pal, R., G. M. Hoke, and M. G. Sarngadharan. 1989. Role of oligosaccarides in the processing and maturation of envelope glycoproteins of human immunodeficiency virus type 1. Proc. Natl. Acad. Sci. USA. 86:3384-3388.

32. Sunyoung, K., R. Byrn, J. Groopman, and D. Baltimore. 1989. Temporal aspects of DNA and RNA synthesis during human immunodeficiency virus infection: evidence for differential gene expression. J. Virol. 63:3708-3713.

33. Lu, J., W. A. Baase, D. C. Muchmore, and F. W. Dahlquist. 1992. Protein folding: assignment of the energetic changes of reversible chemica modifications to the folded or unfolded states. Biochemistry. 31:7765-7772.

34. Chandra, A., I. Demirhan, S. K. Arya, and P. Chandra. 1988. D-penicillamine inhibits transactivation of human immunodeficiency virus type-1 (HIV-1) LTR by transactivator protein. FEBS (Fed. Eur. Biochem. Soc.) Lett. 236:282286

35. Scheib, R. G., D. M. Parenti, G. L. Simon, J. W. Courtless, R. S. Schulof, P. S. Sarin, and P. Chandra. 1987. Prolonged antiviral activity of D-penicillamine in human immunodeficiency virus-infected homosexual men. Am. J. Med. 83:608.

36. Kubota, S., M. A. El-Farrash, M. Maki, S. Harada, and M. Hatanaka. 1990. 2,3-dimercapto-1-propanol inhibits HIV-1 tat activity, viral production, and infectivity in vitro. AIDS Res. Hum. Retroviruses. 6:919-927.

37. Folks, T. M., K. A. Clouse, J. Justement, A. Rabson, E. Duh, J. H. Kehrl, and A. S. Fauci. 1989. Tumor necrosis factor alpha induces expression of human immunodeficiency virus in a chronically infected T-cell clone. Proc. Natl. Acad. Sci. USA. 86:2365-2368.

38. Lahdevirta, J., C. P. J. Maury, A. M. Teppo, and H. Repo. 1988. Elevated levels of circulating cachectin/tumor necrosis factor in patients with acquired immunodeficiency syndrome. Am. J. Med. 85:289-291.

39. Mintz, M., R. Rapaport, J. M. Oleski, E. M. O'Connor, M. R. Koenigsberger, T. Denny, and L. G. Epstein. 1989. Elevated serum levels of tumor necrosis factor are associated with progressive encephalopathy in children with acquired immunodeficiency syndrome. Am. J. Dis. Child. 143:771-774.

40. Klebanoff, S. J., M. A. Vadas, J. M. Harlan, L. H. Sparks, J. R. Gamble, J. M. Agosti, and A. M. Waltersdorph. 1986. Stimulation of neutrophils by tumor necrosis factor. J. Immunol. 136(11):4220-4225.

41. Zimmerman, R. J., B. J., Jr. Marafino, A. Chan, P. Landre, and J. L. Winkelhake. 1989. The role of oxidant injury in tumor cell sensitivity to recombinant human tumor necrosis factor in vivo. Implications for mechanism of action. J. Immunol. 142:1405-1409.

42. Eck, H. P., H. Gmunder, M. Hartmann, D. Petzoldt, V. Daniel, and W. Droge. 1989. Influence of the extracellular glutamate concentration on the intracellular cyst(e)ine concentration in macrophages and on the capacity to release cystein. Biol. Chem. Hoppe-Seyler. 370:101-108.

43. Buhl, R., H. A. Jaffe, K. J. Holroyd, F. B. Wells, A. Mastrangeli, C. Saltini, A. M. Cantin, and R. G. Crystal. 1989. Systemic glutathione deficiency in symptom-free HIV-seropositive individuals. Lancet. 2(8675):1294-1298.

44. Scott, J. S., C. A. Lakin, and J. R. Oliver. 1987. The effect of cysteamine, cystamine, and the structurally related compounds taurine, $\mathrm{N}$-acetyl-cysteine, and D-penicillamine on plasma prolactin levels in normal and estrogen-primed hyperprolactinemic rats. Endocrinology 121:812-818.

45. Markello, T. C., M. E. Bernardini, and W. A. Gahl. 1993. Improved renal function in children with cystinosis treated with cysteamine. N. Engl. J. Med. 328:1157-1162. 